\title{
PENDAMPINGAN DAN PELATIHAN KEWIRAUSAHAAN MASYARAKAT NELAYAN DI TANJUNG GUNDAP
}

\section{MENTORING AND TRAINING OF ENTREPRENEURSHIP TO FISHERMAN COMMUNITY AT TANJUNG GUNDAP, TEMBESI, BATAM}

\author{
Ramon Zamora $^{1^{*}}$, Nurhayati $^{2}$ \\ ${ }^{1}$ Prodi Manajemen, Universitas Riau Kepulauan) \\ ${ }^{2}$ Prodi Ilmu Pemerintahan, Universitas Riau Kepulauan) \\ 1zmr_rmn@yahoo.com, ${ }^{2}$ nurhayati_ip@yahoo.com
}

\begin{abstract}
Abstrak
Kegiatan pengabdian ini bertujuan untuk memberikan pendampingan dan pelatihan dalam menumbuhkembangkan semangat kewirausahaan bagi masyarakat dalam memanfaatkan potensi ekonomi serta meningkatkan pengetahuan dan ketrampilan masyarakat nelayan di Kampung Tua Tanjung Gundap Kelurahan Tembesi Kecamatan Sagulung Kota Batam Propinsi Kepulauan Riau. Metode pelatihan yang diberikan yaitu dalam bentuk pendampingan dan pelatihan (praktek dan teori). Kegiatan tersebut berlangsung selama dua hari berturut turut yaitu dari tanggal 10 Agustus sampai 11 Agustus 2019 dengan jumlah peserta sebanyak 25 orang. Hasil kegiatan Pendampingan dan pelatihan ini diawali dengan perencanaan kegiatan dengan menggunakan analisis SWOT guna menentukan target usaha dan calon-calon usaha, kemudian pengorganisasian tim, yang bertujuan agar ada kejelasan dan tanggung jawab anggota tim antara tugas, wewenang, dan tanggung jawab sesuai dengan bidangnya, Setelah perncanaan kegiatan pelatihan dan penentuan pihak yang terlibat kemudian dilanjutkan dengan mengaplikasikan perencanaan pendampingan yang telah dirancang yang diawali dengan tahap identifikasi dengan cara melakukan observasi langsung ke lapangan untuk menemukenali calon-calon usaha dan kemudian dilanjutkan dengan pendaftaran peserta kegiatan yaitu melalui ketua RT dimintai daftar nama peserta yang sekiranya mau dan mampu mengikuti kegiatan tersebut secara penuh dan terlebih dapat mengembangkan pengetahuan dan keterampilannya pasca pelatihan.
\end{abstract}

Kata Kunci : Pendampingan, Pelatihan, Kewirausahaan, Kampung Tua

\begin{abstract}
This community service activity aims to provide assistance and training in fostering an entrepreneurial spirit for the community in exploiting economic potential and enhancing the knowledge and skills of fishing communities at Kampung Tua Tanjung Gundap, Tembesi, Sagulung District, Batam, Riau Islands Province. The training methods provided mentoring and training (practically and theoretically). The activity was done in two days, from August 10 to August 11, 2019 by involving 25 participants. The results of the mentoring and training activities begun with the planning using SWOT analysis to determine business targets and oriented business, then organizing the team, with the aim to determine the clarity and responsibility of team members about tasks, authorities and responsibilities in accordance to theirs. After planning the training activities and determining the parties involved, then proceeded by applying the planned mentoring plan, which begun from identification stage by conducting direct observations to identify oriented business and then proceeded to the registration stage, by asking a help from head of village to list participants names who were available and had willingness to participate and potentially able to develop thir knowlage and skill post mentoring and training activities.
\end{abstract}

Keywords: Mentoring, Training, Entrepreneurship, Kampung Tua

\section{PENDAHULUAN}

Pengembangan sumberdaya manusia Indonesia perlu dilakukan melalui berbagai cara guna terciptanya sumberdaya manusia yang unggul dan berkualitas. Terkait dengan hal ini 
pemerintah melalui berbagai kebijakan pendidikan yang di keluarkan baik melalui jalur formal, non formal maupun informal (UU RI No. 20 Tahun 2003).

Rendahnya sumberdaya manusia tentunya akan mengakibatkan terbatasnya lapangan pekerjaan dan juga kesempatan kerja, dan keterbatasan tersebut akan mengakibatkan meningkatnya jumlah pengangguran, dimana angka angkatan kerja yang belum memiliki pekerjaan semakin lama akan semakin meningkat apabila hal tersebut tidak cepat ditangani. Pemberdayaan sumberdaya manusia harus dilakukan melalui pemberdayaan masyarakat, layanan pendidikan adalah merupakan salah satu cara untuk mengurangi tingkat pengangguran dan memberantas kemiskinan

Pengembangan kemampuan berwirausaha merupakan alternatif bagi masyarakat untuk lepas dari kemiskinan dan pengangguran. Pengembangan kewirausahaan melalui pelatihan dapat dijadikan salah satu alternatif dan solusi bagi masyarakat.

Menurut Badan Pusat Statistik (BPS) jumlah angkatan kerja di Indonesia pada Agustus 2018 sebanyak 131,01 juta orang, naik 2,95 juta orang dibanding Agustus 2017. Sejalan dengan itu, Tingkat Partsipasi Angkatan Kerja (TPAK) juga meningkat 0,59 persen poin. Pertambahan jumlah angkatan kerja di Indonesia dari tahun ke tahun semakin meningkat namun tidak dibarengi dengan peningkatan jumlah lapangan kerja yang tersedia. Ketidakseimbangan antara jumlah angkatan kerja dengan lapangan kerja tersebut menyebabkan permasalahan penganguran yang cukup kronis.

Upaya penanggulangan masalah tersebut telah dilakukan pemerintah yaitu dengan mencanangkan gerakan kewirausahaan, dimana pemerintah berusaha menciptakan wirausaha yang tangguh dalam menjalankan usahanya dengan memanfaatkan potensi yang ada di daerah. Dalam penjabaran tersebut diperlukan pelatihan bagi mayarakat khususnya di Kampung Tua Tanjung Gundap Kelurahan Tembesi Kecamatan Sagulung Kota Batam dan dengan disertai pemberian contoh yang nyata pada calon pelaku usaha agar memiliki keinginan dan kemauan untuk memulai usaha dan membuka lapangan kerja. Sasaran utama dalam pemberian pelatihan tersebut adalah masyarakat dan nelayan di Kampung Tua Tanjung Gundap yang mempunyai potensi yang besar untuk memulai usaha dan mengembangkanya di masa depan sehingga mempunyai multiplayer effect yang besar terhadap penciptaan lapangan kerja. 
Pelatihan adalah usaha yang terencana untuk meningkatkan keterampilan dan sikapsikap yang relevan terhadap pekerjaan. Pengertian tersebut senada dengan pendapat Aditya (2015) yang menyatakan bahwa pelatihan merupakan usaha peningkatan bakat, keterampilan, kecakapan, kemampuan dan keahlian dalam menghadapi tugas. Sedangkan Mangkunegara (2014), “istilah pelatihan ditujukan pada pegawai pelaksana untuk meningkatkan pengetahuan dan keterampilan teknis”. Sedangkan kewirausahaan merupakan proses menciptakan atau menambah nilai jual sesuatu dengan semangat dan perilaku yang kreatif, inovatif, serta kemampuan manajemen.

Menurut Nurbudiyani (2013) kewirausahaan merupakan ilmu untuk mempelajari tentang nilai, kemampuan, sikap, dan perilaku seseorang dalam memenuhi tantangan hidup. Dari beberapa pengertian tersebut di atas dapat disimpulkan bahwa pelatihan kewirausahaan merupakan suatu usaha atau kegiatan yang dilaksanakan dengan sadar dan terencana guna untuk meningkatkan keterampilan serta menghasilkan nilai tambah suatu produk.

Tumbuh kembangnya kewirausahaan ditengah masyarakat Kampung Tua Tanjung Gundap diharapkan mampu memberikan manfaat dan kontribusi langsung baik sifatnya finansial maupun non finansial. Manfaat finansial berupa kemandirian ekonomi yang diperoleh dalam menjalankan usaha. Sedangkan manfaat non finansial adalah tumbuhnya mental yang tangguh dan semangat pantang menyerah dalam menghadapai permasalahan.

Tanjung Gundap merupakan salah satu kampung tua yang berada dipesisir Kota Batam, secara administrasi berada dalam kelurahan Tembesi Kacamatan Sagulung Kota Batam, dan terletak antara $0^{0} 55^{\prime}$ - 1055' Lintang Utara, 103045' -104010' Bujur Timur.Tanjung Gundap terdiri dari 1 (satu) Rukun Warga dan 2 (dua) Rukun Tetangga (RT) Keadaan permukaan tanah di Tanjung Gundap pada umumnya berombak dan sebagian wilayah berada di pesisir pantai, dengan ketinggian $2 \mathrm{Mdpl}$ (Meter di atas permukaan laut).

Sama halnya dengan daerah lain di Kota Batam, Kampung Tua Tanjung Gundap beriklim tropis dengan suhu minimum berkisar $18,2^{\circ} \mathrm{C}-23,0^{\circ} \mathrm{C}$ dan suhu maksimum berkisar $31,0^{\circ} \mathrm{C}-343,2^{\circ} \mathrm{C}$. Penduduk warga Tanjung Gundap umumnya adalah nelayan mengingat letak daerah tersebut yang berada dipesisir, dan sebagian lagi adalah wiraswasta.

Berdasarkan analisis situasi di atas dapat diidentifikasi dan perumusan masalah sebagaimana diuraikan bawah: Rendahnya pengetahuan mayarakat tentang nilai ekonomi suatu komoditas yang dihasilkan; Masih minimnya keterampilan masyarakat khususnya 
nelayan dalam mengelola hasil tangkapnya; Kurangnya tingkat pengetahuan masyarakat terhadap hasil potensi laut; Belum optimal dan terfokusnya pembinaan bagi para pelaku UMKM; Belum berkembangnya kemampuan wirausaha dalam melakukan peningkatan kualitas hidup.

\section{METODOLOGI}

Metode pelatihan yang diberikan yaitu dalam bentuk pendampingan dan pelatihan (praktek dan teori). Dimana kegiatan tersebut berlangsung selama dua hari bertutur-turut yaitu dari tanggal 10 Agustus sampai 11 Agustus 2019 dengan jumlah peserta sebanyak 25 orang, dimana peserta diajak unuk memahami tujuan, manfaat berwirausaha.

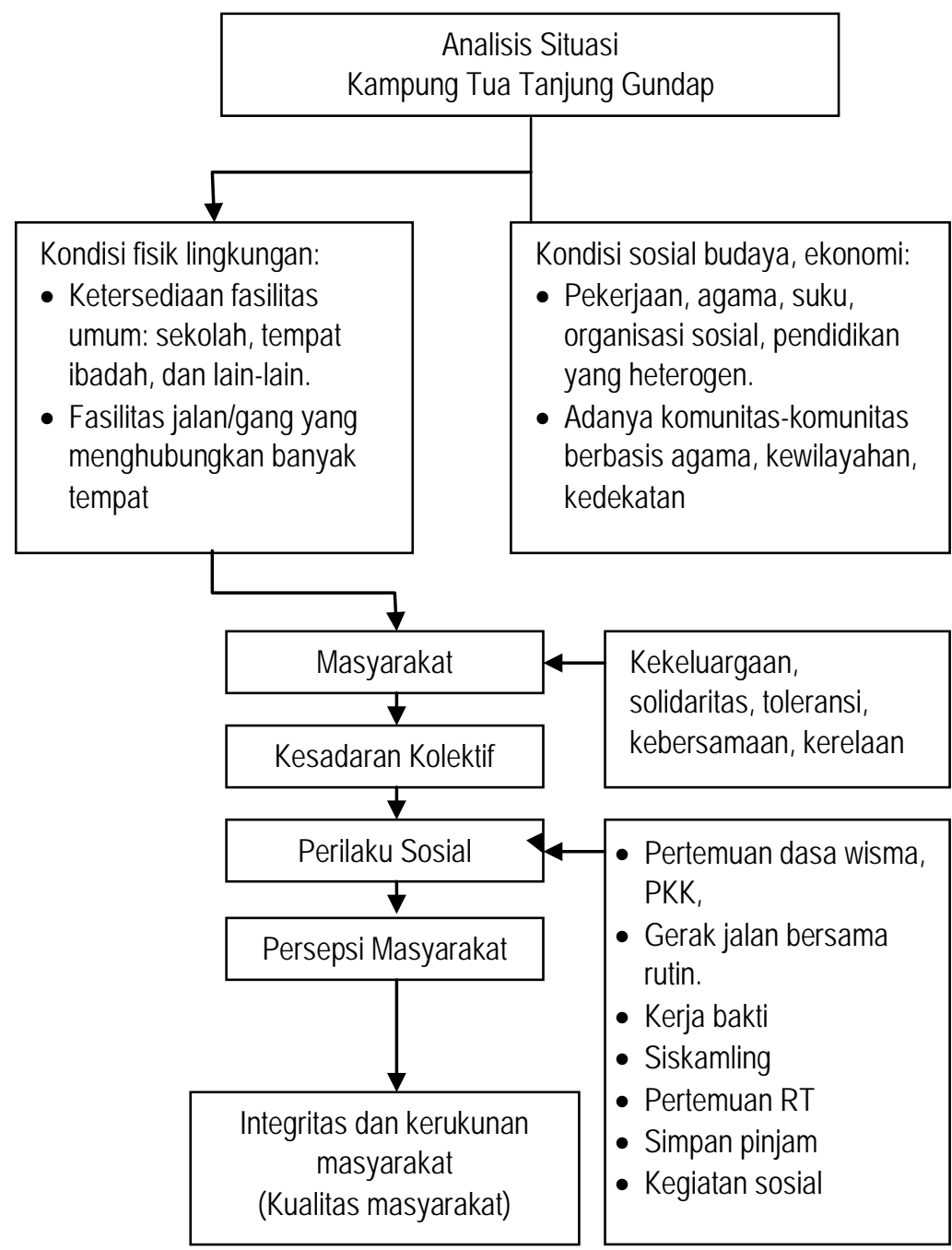

Figur 1. Alur Potensi dan kondisi sosial ekonomi budaya masyarakat Kampung Tua Tanjung Gundap 
Penyajian materi yang berkaitan dengan pentingnya wirausaha melalui proses belajar mandiri dan kelompok, tujuan dan manfaat praktis dari kegiatan tersebut. Pada pertemuan pertama semua peserta diberikan pemahaman-pemahaman tentang wirausaha. Materi lain yang disampaikan adalah berupa menyadarkan dan menumbuhkan minat kepada masyarakat dan Nelayan Tanjung Gundap tentang kewirausahaan meski dengan modal minimal serta memanfaatkan sedikit ruang untuk melakukan aktivitas yang menyehatkan, produktif atau minimal usaha untuk memperbaiki kesejehteraan keluarga melalui pemanfaatan hasil laut.

Program pengabdian pada masyarakat yang berlokasi di Kampung Tua Tanjung Gundap ini berlangsung selama 2 (dua) yaitu hari Sabtu dan Minggu, tanggal 10 Agustus sampai 11 Agustus 2019 dengan jumlah peserta kegiatan sebanyak 25 (dua puluh lima) orang, peserta kegiatan adalah masyarakat yang menetap dan berdomisili di Kampung Tua Tanjung Gundap, nara sumber kegiatan berasal dari akademisi dan pengusaha serta dari perbankan khusus materi dengan tema pembiayaan dan permodalan UMKM melalui KUR. Sedangkan narasumber lain dengan materi menjelaskan mengenai pelatihan wirausaha.

\section{PEMBAHASAN}

\section{Perencanaan Kegiatan}

Perencanaan pendampingan dan pelatihan kewirausahaan di Kampung Tua Tanjung Gundap ini dilakukan secara matang guna untuk mendapatkan hasil yang maksimal serta berarti bagi masyarakat. Menurut Kurniadin \& Machali (2012:127) mengemukakan bahwa aspek perencanaan meliputi (a) apa yang dilakukan; (b) siapa yang melakukan; (c) kapan dilakukan; (d) di mana dilakukan; (e) bagaimana melakukannya; dan (f) apa saja yang diperlukan agar tercapai tujuan secara maksimal. Kegiatan perencanaan ini diawali dengan pembentukan Tim Pengabdi yang di SK kan oleh Lembaga Penelitian dan Pengabdian kepada Masyarakat (LPPM) Universitas Riau Kepulauan Batam, kemudian dilanjutkan dengan meeting antara Tim Pengabdi, Pemerintah Setempat, Tokoh Masyarakat Tanjung Gundap, pembina kewirausahaan, serta mahasiswa yang terlibat langsung dalam kegiatan ini. Pada perencanaan pelatihan kewirausahaan, aspek-aspek yang direncanakan meliputi motivasi, mindset kewirausahaan, keuangan/permodalan, pemasaran, dan produksi. Aspek-aspek yang direncanakan memang lebih mengarah ke manajemen usaha, karena diharapkan setelah kegiatan ini masyarakat/calon wirausaha dapat terjun langsung ke dunia usaha. 
Dalam perencanaan pelatihan kewirausahaan di Kampung Tua Tanjung Gundap juga dilakukan dengan menggunakan analisis SWOT guna menentukan target usaha dan caloncalon usaha. Sebelum menentukan target, kegiatan yang tak kalah penting yang dilakukan Tim adalah melakukan identifikasi/analisis usaha masayarakat. Analisis ini dimaksudkan untuk mengetahui apa yang masayarakat inginkan sehingga mampu diupayakan strategi yang akan digunakan. Menurut Manulang (2002:9), perencanaan diartikan sebagai penetapan tujuan, policy, prosedur, budget, dan program dari suatu organisasi.

\section{Pengorganisasian Tim}

Pengorganisasian atau pembentukan tim Pengabdi kepada Masyarakat Universitas Riau Kepulauan adalah merupakan kegiatan yang tak kalah penting dari perencanaan diatas, pengorganisasian ini bertujuan agar ada kejelasan dan tanggung jawab anggota tim antara tugas, wewenang, dan tanggung sesuai dengan bidangnya. Menurut Kurniadin \& Machali (2009:130), pengorganisasian berarti menciptakan suatu struktur dengan bagian-bagian yang terintegrasi sehingga mempunyai hubungan yang saling mempengaruhi satu sama lain. Dengan adanyan struktur organisasi maka tugas pokok dan fungsi (tupoksi) anggota yang terlibat akan semakin jelas dan mudah dipahami.

Pandampingan Pelatihan kewirausahaan di Kampung Tua Tanjung Gundap berada dibawah naungan Lembaga Penelitian dan Pengabdian Masyarakat Universitas Riau Kepulauan Batam. Juharyanto (2017:96), terdapat Sembilan perilaku kepemimpinan dalam kewirausahaan dalam mewujudkan wirausaha yang efektif yaitu: “(a) budaya independensi yang kuat; (b) pemahaman visi yang jelas; (c) yakin atas keberhasilan; (d) budaya belajar sepanjang hayat; (e) kekuatan imajinasi; (f) berbasis nilai multidimensional; (g) pemberdayaan; (h) kolegialitas; dan (i) nilai juang”. Selain melibatkan dosen, kegiatan ini juga melibatkan, mahasiswa semester akhir menjadi bagian dari pelatih kewirausahaan, oleh karena itu koordinasi antara satu sama lain sangatlah penting dilakukan, selain koordinasi komunikasi sesama anggota juga diperlukan .

\section{Pelaksanaan Kegiatan}

Setelah perncanaan kegiatan pelatihan dan penentuan pihak yang terlibat kemudian dilanjutkan dengan mengaplikasikan perencanaan pendampingan yang telah dirancang 
sebelumnya menurut Suwatno \& Donni (2011: 132) yaitu “melakukan persiapan, menyajikan dan memberi kesempatan untuk mencoba, serta membiarkan peserta untuk melaksanakan pekerjaannya, dengan melalui beberapa tahapan, tahap pertama adalah identifikasi dengan cara melakukan observasi langsung ke lapangan untuk menemukenali calon-calon usaha dan kemudian dilanjutkan dengan pendaftaran peserta kegiatan yaitu melalui ketua RT dimintai daftar nama peserta yang sekiranya mau dan mampu mengikuti kegiatan tersebut secara penuh dan terlebih dapat mengembangkan pengetahuan dan keterampilannya pasca pelatihan.

Selanjutnya adalah sesi pemberian motivasi. Materi ini disampaikan selama kurang lebih 2 jam dimulai dari jam 10.30 sampai dengan jam 12.30 diselingi dengan permainan/game-game. Penyampaian materi ini juga diikuti dengan sesi tanya jawab dengan peserta dimana pada sesi ini para peserta pelatihan mendapatkan kesempatan untuk bertanya langsung dengan pemateri. Pertanyaan-pertanyaan yang diajukan antara lain adalah seputar penumbuhan semangat berwirausaha.

Sesi berikutnya adalah berupa pemberian materi pelatihan yang disampaikan oleh narasumber dari Tim Pengabdi secara bergantian. Materi yang disampaikan antara lain tentang Motivasi, Mindset Entrepreneur, Kreativitas Pemanfaatan Medsos untuk Pemasaran Produk

Pada hari kedua, tim menyampaikan materi mengenai business plan beserta prakteknya dan Setelah seluruh materi selesai disampaikan, selanjutnya para peserta pelatihan diminta untuk membentuk kelompok dengan beranggotakan 5 orang tiap kelompok. Masingmasing kelompok ini dibimbing untuk merencanakan ide usaha yang selanjutnya dituangkan dalam bentuk business plan dan studi kelayakan usaha. Business plan dan studi kelayakan usaha yang telah disusun kemudian dipresentasikan.

Sesi terakhir sebelum penutupan, kegiatan pengabdian pada masyarakat ini peserta disajikan demonstrasi mengolah hasil laut khususnya Ikan segar agar menambah nilai ekonomisnya dan juga pengolahan hasil laut selain ikan. Kegiatan pelatihan kemudian ditutup pada pukul 15.45 .

Acara pelatihan kewirausahaan ini berlangsung dengan baik. Hal tersebut dapat dilihat dari antusiasnya masyarakat yang ikut dan juga mendapat dukungan penuh dari RW, RT, Tokoh Masyarakat dan Pemuda di Kampung Tua Tanjung Gundap. Bantuan yang dukungan yang diberikan baik penyediaan sarana serta publikasi terhadap peserta. Faktor pendukung 
lainnya adalah peserta yang memiliki minat dan ketertarikan di bidang wirausaha sehingga dalam mengikuti acara tersebut peserta terlihat kritis dan antusias.

\section{KESIMPULAN DAN SARAN}

Perencanaan pelatihan dan pendampingan Kewirausahaan masyarakat dan nelayan ini dilaksanakan di Kampung Tua Tanjung Gundap kelurahan Tembesi Kecamatan Sagulung kota Batam dengan jumlah peserta sebanyak 25 orang berjalan dengan baik, hal ini tidak lepas dari dukungan masyarakat dan pemerintah setempat, kedepannya kegiatan ini perlu ditingatkan terutama mengenai jumlah fasilitor pendamping, cakupan wilayah serta jumlah perserta dan durasi waktu kegiatan.

Pengorganisasian atau pembentukan tim Pengabdi kepada Masyarakat berada dibawah naungan Lembaga Penelitian dan Pengabdian Universitas Riau Kepulauan. Pada tahapan pengorganisasi ini juga perlu adanya keterlibatan Karang Taruna atau organisasi kepemudaan setempat serta ibu-ibu kader PKK yang termasuk sebagai anggota Tim Kegiatan yang di SK kan oleh LPPM.

Pelaksanaan kegiatan pengabdian Adapun materi yang dibahas meliputi aspek-aspek yang direncanakan meliputi motivasi usaha, keuangan/modal, produksi dan pemasaran. Pelaksanaan kegiatan dilaksanakan selama 2 (dua) hari yaitu hari Sabtu dan Minggu tanggal 10 Agustus sampai 11 Agustus 2019 yang terdiri dari beberapa sesi kegiatan. Kedepannya perlu adanya penyesuaian materi, dan juga pembicara yang memiliki kompetensi dengan bidangnya masing-masing.

\section{REFERENSI}

Aditya, R., I. 2015. Pengaruh Pelatihan terhadap Kompetensi dan Kinerja Karyawan (Studi pada Karyawan PT. PLN (Persero) Distribusi Jawa Timur Area Malang). Jurnal Administrasi Bisnis, Vol. 2(27): 1-6.

Badan Pusat Statistika. 2018. Angka Pengangguran (2018). https://bps.go.id/ Brs/view/id/1376 ), diakses 8 Desember 2018

Juharyanto. 2017. Kepemimpinan Unggul Kepala Sekolah Dasar Daerah Terpencil (Studi Multisitus pada Sekolah Dasar di Kabupaten Bondowoso. Jurnal Pendidikan, Vol. 26(1): 89-100. 
Kurniadin, D., \& Machali, I. (2009). Manajemen Pendidikan: Konsep dan Prinsip Pengelolaan Pendidikan. Terbitan I. Yogyakarta: Ar-Ruzz.

Kurniadin \& Machali, II. (2012). Manajemen Pendidikan: Konsep dan Prinsip Pengelolaan Pendidikan. Terbitan II. Yogyakarta: Ar-Ruzz.

Mangkunegara, A.M. (2014). Perencanaan dan Pengembangan Sumber Daya Manusia. Bandung: PT. Refika Aditama.

Manulang, M. (2002). Dasar-Dasar Manajemen. Yogyakarta: Gadjah Mada University Press.

Nurbudiyani, I. (2013). Model Pembelajaran Kewirausahaan dengan Media Koperasi Sekolah di SMK Kelompok Bisnis dan Manajemen. Jurnal Pendidikan Vokasi, Vol. 1(3):5367.

Suwatno \& Donni. (2011). Manajemen SDM dalam Organisasi Publik dan Bisnis. Bandung: Alfabeta. 